\title{
Robson classification of caesarean sections in two Polish centres on different levels of reference
}

\section{Klasyfikacja Robsona cięć cesarskich - ocena w dwóch ośrodkach na różnych poziomach referencyjności}

\author{
Jakub Młodawski1,2, Marta Młodawska, Mateusz Nowak³ , Aleksandra Michalska4, Kinga Kapturska4, \\ Katarzyna Kozubal ${ }^{4}$, Wojciech Kocemba ${ }^{3}$, Grzegorz Świercz ${ }^{1,2}$ \\ ${ }^{1}$ Collegium Medicum, Jan Kochanowski University, Kielce, Poland \\ Head of the Collegium: Prof. Marianna Janion \\ ${ }^{2}$ Clinic of Obstetrics and Gynaecology, Provincial Combined Hospital, Kielce, Poland \\ Head of the Clinic: Grzegorz Świercz MD, PhD \\ ${ }^{3}$ Department of Obstetrics and Gynaecology, Tomaszów Health Centre, Tomaszów, Poland \\ Head of the Department: Wojciech Kocemba MD, PhD \\ ${ }^{4}$ Eskulap, Student Scientific Organization-Collegium Medicum, Jan Kochanowski University, Kielce, Poland
}

Key words: Robson classification, The 10-Group Classification System, Caesarean section.

Słowa kluczowe: klasyfikacja Robsona, klasyfikacja dzisięciu grup Robsona, cięcie cesarskie.

\begin{abstract}
Introduction: Caesarean section (CS) is one of the most common abdominal surgeries performed in the world. The 10-Group Classification System (TGCS, Robson classification) is a World Health Organization recommended classification assessing indications based on 5 variables (parity, previous caesarean section, labour onset, foetal presentation, gestational age, and number of fetuses). The TGCS provides the opportunity to compare indications between different countries, audit, and evaluate of the quality and impact of the recommendations.

Aim of the research: Classification of CS data derived from 2 centres according to the TGCS.

Material and methods: We used the above-mentioned tool to classify 2000 Caesarean sections from two centres - II and III degree of reference.

Results: In both groups, group 5 (RG5 - Robson group 5) constituted the largest part of all Caesarean sections, at 39.9\% and $35.17 \%$, respectively. The sum of groups from 1 to 4 (RG 1-4) had a relative contribution to the total number of Caesarean sections in individual centres of $46.94 \%$ and $53.48 \%$, respectively. The percentage of occurrence of particular classes was similar in both centres.

Conclusions: The results of our study are an attempt to determine the trend in indications for Caesarean sections according to the TGCS in Poland and to popularize the tool used according to WHO recommendations. All activities aimed at effective reduction of the number of Caesarean sections in Poland should be aimed primarily at reducing the percentage of Caesarean sections in the RG5 group.
\end{abstract}

\section{Streszczenie}

Wprowadzenie: Cięcie cesarskie (CC) to jedna z najczęściej wykonywanych operacji brzusznych na świecie. System Robsona oparty na 10 grupach (TGCS - The 10-Group) jest klasyfikacją CC zalecaną przez Światową Organizację Zdrowia. Pacjentki klasyfikowane są na podstawie 5 zmiennych (rodność, obecność blizny po CC na macicy, rozpoczęcie porodu, położenie i liczba płodów oraz wiek ciążowy). TGCS umożliwia porównanie wskazań między różnymi krajami, audyt ośrodków oraz ocenę wpływu zaleceń.

Cel pracy: Klasyfikacja CC według TGCS.

Materiał i metody: Przy użyciu TGCS sklasyfikowaliśmy 2000 CC z dwóch ośrodków - II i III stopnia referencyjności.

Wyniki: W obu grupach grupa 5 (RG5 - Robson group 5) stanowiła największy odsetek wszystkich CC, odpowiednio 39,9\% i 35,17\%. Suma grup od 1 do 4 (RG 1-4) miała względny udział w ogólnej liczbie CC w poszczególnych ośrodkach, odpowiednio 46,94\% i 53,48\%. Odsetek występowania poszczególnych klas był podobny w obu ośrodkach.

Wnioski: Wyniki naszego badania są próbą określenia trendu wskazań do CC według TGCS w Polsce oraz popularyzacji tego narzędzia. Wszystkie działania mające na celu efektywne zmniejszanie liczby CC w Polsce powinny być ukierunkowane na zmniejszanie liczby pacjentek klasyfikowanych do grupy 5. 


\section{Introduction}

Caesarean section (CS) is undoubtedly a procedure that reduces maternal and neonatal mortality and morbidity in certain obstetric situations. In Poland, almost every second delivery takes place through CS. The percentage of caesarean sections in Poland is above the average for OECD countries and has an upward trend $[1,2]$. In 2015 , the WHO proposed use of the TGCS (TGCS = 10-Group Classification System, Robson Classification) (Table 1) to globally standardize indications for caesarean sections (post factum) and, consequently to be able to compare indications between countries and assess the impact of new recommendations on trends $[3,4]$. The classification categorizes patients according to 5 variables (parity including previous caesarean, labour onset, foetal presentation, gestational age and number of fetuses). In Poland, this classification is currently not a commonly used tool. However, data from individual centres suggest that the most common indication remains the state after previous Caesarean section [5], which in the TGCS classification when foetus is in the cephalic presentation after 37 weeks corresponds to category 5 (RG5 - Robson group 5). In our paper we decided to analyse the indications for CS in 2 centres from the province of Lodzkie and Swietokrzyskie in order to obtain a sample of the trend of the distribution of indications in our country.

Table 1. Description of particular TGCS (10-Group Classification System) groups (RG - Robson group)

\begin{tabular}{|ll|}
\hline TGCS group & \multicolumn{1}{c|}{ Description } \\
RG1 & $\begin{array}{l}\text { Nulliparous, single cephalic, } \geq 37 \text { weeks, } \\
\text { spontaneous labour }\end{array}$ \\
RG3 & $\begin{array}{l}\text { Nulliparous, single cephalic, } \geq 37 \text { weeks, } \\
\text { induced or Caesarean before labour }\end{array}$ \\
RG4 & $\begin{array}{l}\text { Multiparous (excluding previous } \\
\text { Caesareans), single cephalic, } \geq 37 \text { weeks, } \\
\text { spontaneous labour }\end{array}$ \\
RG5 & $\begin{array}{l}\text { Multiparous (excluding previous } \\
\text { Caesareans), single cephalic, } \geq 37 \text { weeks, } \\
\text { induced or Caesarean before labour }\end{array}$ \\
RG6 & $\begin{array}{l}\text { Previous Caesarean, single cephalic } \\
\geq 37 \text { weeks } \\
\text { RG7 }\end{array}$ \\
All nulliparous breeches \\
RG8 & $\begin{array}{l}\text { All multiparous breeches (including } \\
\text { previous Caesareans) }\end{array}$ \\
RG9 & $\begin{array}{l}\text { All multiple pregnancies (including } \\
\text { previous Caesareans) }\end{array}$ \\
RG10 & $\begin{array}{l}\text { All abnormal lies (including previous } \\
\text { Caesareans) } \\
\text { All single cephalic, } \leq 36 \text { weeks (including } \\
\text { previous Caesareans) }\end{array}$ \\
\hline
\end{tabular}

\section{Aim of the research}

The aim of the study was to analyse indications for Caesarean sections in selected centres of II and III degree of reference according to Robson criteria.

The study was not intended to compare centres but only to attempt to determine the general trend.

\section{Material and methods}

We retrospectively analysed indications for 2000 consecutive caesarean sections starting from the beginning of 2018 from 2 centres - II and III reference facilities (Clinic of Obstetrics and Gynaecology, Provincial Combined Hospital in Kielce (reference facility level III - RFLIII) $-n=1000$ and Department from Obstetrics and Gynaecology, Tomaszów Health Centre (reference facility level II - RFLII) $-n=1000$ ).

\section{Results}

The results of relative contribution in relation to the total number of Caesarean sections in a given centre (which is 100\%) are presented in Table 2 and Figure 1. The total RG1-4 was $46.94 \%$ in RFLII and $53.48 \%$ in RFLIII.

\section{Discussion}

Caesarean section should be an option for every patient who has indications for it, but epidemiological data do not indicate that an increase of more than $15 \%$ will bring benefit to the population in terms of reducing maternal and neonatal mortality and morbidity $[6,7]$. The basic principle that should guide any health care system is to ensure that a Caesarean section can be performed for every patient who needs

Table 2. Relative contribution for the total number of Caesarean sections in a given centre (RFLII - reference facility level II, RFLIII - reference facility level IIII, RG - Robson group) (percentage of total Caesarean sections number in a particular facility)

\begin{tabular}{|lcc|}
\hline Robson category & RFLII & RFLIII \\
RG1 & $22.98 \%$ & $18.60 \%$ \\
RG2 & $12.47 \%$ & $19.96 \%$ \\
RG3 & $6.72 \%$ & $9.88 \%$ \\
RG4 & $4.77 \%$ & $5.04 \%$ \\
RG5 & $39.90 \%$ & $35.17 \%$ \\
RG6 & $4.91 \%$ & $5.14 \%$ \\
RG7 & $2.20 \%$ & $1.16 \%$ \\
RG8 & $2.22 \%$ & $1.45 \%$ \\
RG9 & $2.11 \%$ & $0.10 \%$ \\
RG10 & $1.71 \%$ & $3.49 \%$ \\
\hline
\end{tabular}




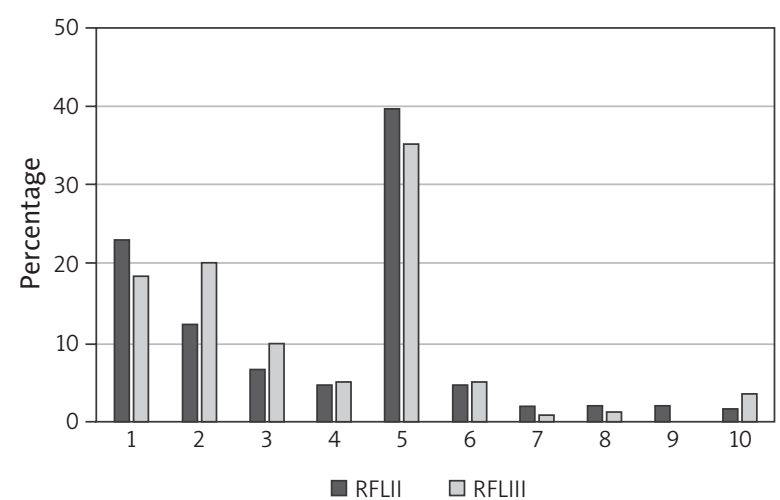

Figure 1. Distribution of relative contribution of Robson groups to the total number of Caesarean sections in particular facilities

it in order to save the health of the mother and/or child. It should be remembered that, especially from a mother's perspective, each procedure has potential complications - both short and long term $[6,8]$. There are also reports that a delivery by Caesarean section may adversely affect the immune system of children, and increase the risk of asthma, juvenile arthritis, inflammatory bowel disease, and leukaemia [9], so the decision to perform a CS should be based on current medical knowledge to properly balance risks and benefits. The data collected by us showed that approximately $37 \%$ of caesarean sections in both centres are performed in single, full-term pregnancies, after previous Caesarean section in the history, with the foetus in the cephalic presentation. According to unpublished data collected at the RFLIII centre, approximately $90 \%$ of these CS are elective repeat Caesarean delivery (ERCD). Obviously, the results obtained by us cannot be extrapolated to all obstetrics and gynaecology departments in Poland, but taking into account the large disproportion between the percentage of R5 category prevalence and the other categories in both centres, it is highly probable that this is the class to which CSs in Poland are most often categorized. The obtained data are consistent with the literature data from other countries. In most of the works, RG5 has the largest proportionate contribution to the total Caesarean sections. In the United States, RG5 accounted for > 34\% of the overall 2014 Caesarean delivery rate [10], in Austria it accounted for $26.9 \%$ with an upward trend [11], and in Brazil it was also the most common group of indications, accounting for approximately 31.3\% [12]. Any attempts to limit the number of CSs should be directed at this group of patients. An obvious action aimed at reducing the presence of this category is to encourage trial of labour after CS (TOLAC). With appropriate qualification, it is safe, and the outcome in the form of vaginal birth after caesarean section (VBAC) is statistically most favourable from the point of view of the newborn and the mother [1]. The absolute risk of the most severe complication of TOLAC from the point of view of both mother and child - intrapartum uterine rupture - is less than $0.5 \%$, and the overall risk of maternal and perinatal death is more than 3 times lower with TOLAC than with ERCD (0.004\% vs. $0.013 \%$ ) [13]. From a population point of view, intrapartum uterine rupture is mainly associated with an increased risk to the newborn. Research indicates that the overall perinatal mortality among patients taking TOLAC is two and a half times higher, at $0.13 \%$ vs. $0.05 \%$ [13]. It is worth noting, however, that the values are lower than the absolute value of perinatal mortality in Poland, which was $0.38 \%$ in 2018 [2]. Appropriate qualification for TOLAC is the key to reducing the frequency of this indication while maximizing safety. Responding to this need, the Polish Society of Gynaecologists and Obstetricians in its recommendations from 2018 changed the previously binding recommendations, abolishing the obligatory consent of the patient to TOLAC in the case of spontaneous initiation of labour and in the absence of factors increasing the risk of scar dehiscence [14]. In Poland, there is no system monitoring the population implications of recommendations issued by scientific societies, so the practical population effect of such guidelines remains immeasurable. Popularizing the TGCS could fulfil such a function.

An important indicator of the TGCS is also the total proportion of RG1-4 patients in the centres, because it is a measure of Caesarean sections performed among patients who are the most optimal group for vaginal delivery (nulliparous or multiparous, cephalic presentation, completed 37 weeks without previous uterine scar). It is also a group of patients who will most likely be classified under RG5 in the event of their next pregnancy. These are also female patients who may potentially be candidates for childbirth outside hospital conditions. An increasing trend of interest in this type of birth is observed in our country [15]. In our analysis, every second patient in the combined RG1-4 group underwent Caesarean section. This corresponds to trends in other developed countries such as the United States - 47\% (10), Austria - 64\% (11), and Turkey - 66\% [16]. It is worth noting that among these patients, there are both patients whose section was performed intrapartum during spontaneous and induced labour, as well as patients whose section was performed before the onset of labour - elective Caesarean section. In order to distinguish patients from these 2 categories, modified Robson criteria were described. In this modification, by adding letters to the number, additional subgroups were established depending on whether delivery was spontaneous (a), induced (b), or CS before labour (c). Such subclassification is important from an epidemiological point of view. Each year more deliveries 
in the world are induced [17], and local algorithms of proceedings differ both in terms of indications and way of pre-induction. The need of pre-induction of labour (in case of low Bishop score) is an adverse factor a priori in relation to successful vaginal delivery [18]. Given the numerous methods of pre-induction of delivery, the widespread use of modified Robson criteria could be a kind of quality-control for applicable procedure of labour induction. The Robson system with subcategorization is recommended for use by the Society of Obstetricians and Gynaecologists of Canada $[19,20]$.

The limitation of this study is the lack of use of modified criteria. The second limitation is the lack of assessment of what percentage of the total number of pregnant patients from a given RG is subjected to CS. We limited ourselves only to showing the relative contribution of CS in each RG in relation to the total number of CS in a given centre.

\section{Conclusions}

The trend in the distribution of CS in TGCS in both centres is similar to that observed in developed countries.

Effective actions aimed at reducing the number of CS in Poland should be directed mainly at reducing the share of RG5, due to the high relative contribution of this group.

The Robson classification is a useful tool for the assessment of indications for CS, and its widespread use would enable the proper assessment of indications and the impact of the introduced recommendations on the general trend.

\section{Acknowledgments}

Project financed under the program of the Minister of Science and Higher Education called "Regional Initiative of Excellence" in the years 2019-2022, project no. 024/RID/2018/19, amount of financing $11,999,000.00 \mathrm{zł}$.

\section{Conflict of interest}

The authors declare no conflict of interest.

\section{References}

1. Rokita W, Młodawski J. Vaginal birth after caesarean section-qualification, outcomes and complications. Ginekol Perinatol Prakt 2018; 3: 1-9.

2. OECD/European Union (2018), Health at a Glance: Europe 2018: State of Health in the EU Cycle, OECD Publishing, Paris/European Union, Brussels, https://doi. org/10.1787/health glance_eur-2018-en.

3. Robson M, Murphy M, Byrne F. Quality assurance: The 10-Group Classification System (Robson classification), induction of labor, and cesarean delivery. Int J Gynaecol Obstet 2015; 131 Suppl 1: S23-S27.
4. Robson MS. Classification of caesarean sections. Fetal Matern Med Rev 2001; 12: 23-39.

5. Santorek N, Biłas K, Tokarska A, Zarzycka K, Kasprzak P, Kwiatkowski S, Torbe A. Cięcie cesarskie. Rosnący odsetek i zmiana trendów we wskazaniach. Ginekol Perinatol Prakt 2019; 4: 113-122.

6. Ye J, Betrán AP, Guerrero Vela M. Searching for the optimal rate of medically necessary cesarean delivery. Birth 2014; 41: 237-244.

7. Mlodawski J Mlodawska M, Pazera G, Michalski W, Domanski T, Dolecka-Slusarczyk M, Gluszek S, Rokita W. Cerebral palsy and obstetric-neonatological interventions. Ginekol Pol 2019; 90: 722-727.

8. Nashibi R, Khosravi A, Bakhtiary E, Shiravi M. Evaluation of risk factors and the epidemiological pattern of nosocomial infection after gynaecological surgery in Ahvaz Imam Khomeini Hospital during the period 2011-2016. Medical Studies 2020; 36: 26-30.

9. Sevelsted A Stokholm J, Bønnelykke K, Bisgaard H. Cesarean section and chronic immune disorders. Pediatrics 2015; 135: e92-e98.

10. Hehir MP, Ananth CV, Siddiq Z, Flood K, Friedman AM, D'Alton ME. Cesarean delivery in the United States 2005 through 2014: a population-based analysis using the Robson 10-Group Classification System. Am J Obstet Gynecol 2018; 219: 105.e1-105.e11.

11. Bracic T, Pfniß I, Taumberger N, Kutllovci-Hasani K, Ulrich D, Schöll W, Reif P. A 10 year comparative study of caesarean deliveries using the Robson 10 group classification system in a university hospital in Austria. PLoS One 2020; 15: e0240475.

12. Rudey EL Leal MDC, Rego G. Cesarean section rates in Brazil: trend analysis using the Robson classification system. Medicine 2020; 99: e19880.

13. Guise JM, Eden K, Emeis C, Denman MA, Marshall N, Fu RR, Janik R, Nygren P, Walker M, McDonagh M. Vaginal birth after cesarean: new insights. Evid Rep Technol Assess 2010; 191: 1-397.

14. Wielgos M, Bomba-Opoń D, Bręborowicz G, Czajkowski K, Debski R, Leszczynska-Gorzelak B, Oszukowski P, Radowicki S, Zimmer M. Recommendations of the Polish Society of Gynecologists and Obstetricians regarding caesarean sections. Ginekol Pol 2018; 89: 644-657.

15. Nawrot J, Gniadek A, Suder A. Women's interest in birth centre care - is it time to make more options available? Medical Studies 2019; 35: 117-122.

16. Tontus HO, Nebioglu S. Improving the caesarean decision by robson classification: a population-based study by $5,323,500$ livebirth data. Ann Glob Health 2020; 86: 101.

17. Mlodawski J, Mlodawska M, Plusajska J, Galuszewska J, Glijer K, Gluszek S. Misoprostol vaginal insert and Foley catheter in labour induction - single center retrospective observational study of obstetrical outcome. Ginekol Pol 2020; 91: 700-703.

18. Mlodawski J, Mlodawska M, Galuszewska J, Glijer K, Gluszek S. Is unfavourable cervix prior to labor induction risk for adverse obstetrical outcome in time of universal ripening agents usage? Single center retrospective observational study. J Pregnancy 2020; 2020: 4985693.

19. Farine D, Shepherd D. No. 281-Classification of Caesarean Sections in Canada: The Modified Robson Criteria. J Obstet Gynaecol Can 2017; 39: e551-e553. 
20. Farine D, Shepherd D; Special Contributor; Maternal Fetal Medicine Committee. Classification of caesarean sections in Canada: the Modified Robson criteria. J Obstet Gynaecol Can 2012; 34: 976-979.

\section{Address for correspondence:}

\section{Jakub Młodawski MD}

Collegium Medicum

Jan Kochanowski University

Clinic of Obstetrics and Gynaecology

Provincial Combined Hospital

Kielce, Poland

E-mail: jakub.mlodawski@ujk.edu.pl 